\title{
The species of the bee genus Centris Fabricius, 1804 described by Curt Schrottky (Hymenoptera: Apidae)
}

\author{
Felipe Vivallo ${ }^{1}$ \\ ${ }^{1}$ Universidade Federal do Rio de Janeiro (UFRJ), Museu Nacional (MN), Departamento de Entomologia, Laboratório de Hymenoptera. \\ Rio de Janeiro, RJ, Brasil. ORCID: http://orcid.org/0000-0002-4487-0804. E-mail: fvivallo@yahoo.com
}

\begin{abstract}
In this paper the primary types of Centris bees described by the German entomologist Curt Schrottky were studied. The type specimens of C. anisitsi, C. brethesi, C. ehrhardti, C. garleppi, C. garleppi var. unifasciata, C. pectoralis var. flava, C. pocograndensis, and C. xanthocnemis var. perflava were analyzed, providing notes on their current status and depository. To stabilize the application of the name C. ehrhardti a lectotype was designated. Notes and photographs of selected types are also provided.
\end{abstract}

Key-Words. Anthophila; Centridini; Neotropical Region; Solitary bees; Taxonomy.

\section{INTRODUCTION}

Curt Schrottky (1874-1937) was a Russianborn German entomologist that worked mainly in South America (Rasmussen et al., 2009). During his youth he migrated to Brazil and in 1897 he started collecting bees and other insects in Jundiaí, São Paulo state (Rasmussen et al., 2009). Schrottky realized that he was having difficulty identifying the many specimens collected and decided to contact the German melittologist Heinrich Friese (1860-1948) at that time, an authority on bees (Egler, 1963; Rasmussen et al., 2009).

The bee collection made by Schrottky, along with Friese's assistance became an article titled "Ensaio sobre as abelhas solitarias do Brazil" published in by Schrottky in 1902b. That paper was written in Portuguese and it included morphology, diagnoses, notes and keys for species and families, along with the descriptions of new species and varieties. Among the new taxa proposed, were Centris poçograndensis Schrottky, 1902b; C. ehrhardti Schrottky, 1902b, and C. xanthocnemis var. perflava Schrottky, 1902b, all from São Paulo state.

In 1902, Schrottky moved to Argentina, and there he published some articles on new species of Hymenoptera. In Buenos Aires he met some prestigious researchers with which he exchanged specimens, as well as insect dealers who provided him with additional material for his studies (Rasmussen et al., 2009). Among the articles published during that time he described
C. (Rhodocentris) brethesi Schrottky, 1902c and C. (Melanocentris) lynchi Schrottky, 1902a from San Juan province, Argentina, and C. (Melanocentris) furcata var. friesei Schrottky, 1902a from São Paulo state, Brazil. These three new taxa were described adopting the subgeneric categories proposed by Friese (1901), unlike the species he proposed as new in his article on the Brazilian bees (Schrottky, 1902b).

After his short time in Argentina, Schrottky moved to Paraguay, where he spent most of his time studying the unknown hymenopteran fauna of that country (Rasmussen et al., 2009). In 1908, he published an article on the species of the genera Epicharis Klug, 1807 and Hemisia Klug, 1807 - currently a junior synonym of Centris Fabricius, 1804 - from Paraguay. In that article he described $H$. anisitsi Schrottky, 1908; $H$. pectoralis var. clypeata Schrottky, 1908; H. pectoralis var. flava Schrottky, 1908; and H. burgdorfi var. ocellata Schrottky, 1908 all from Asunción, southern Paraguay.

The last Schottky's contribution on new species of the genus Centris was done in 1913 when he described H. garleppi Schrottky, 1913 and H. garleppi var. unifasciata Schrottky, 1913 based on single female specimens collected by Otto Garlepp in southern Peru.

The purpose of this article is to study taxonomically the bee species of Centris described by Schrottky. Their taxonomic status is evaluated, providing information on the depository of the primary types. Relevant notes on the morpholo- 
gy of the species, as well as some photographs, are also provided.

\section{MATERIAL AND METHODS}

The primary types of the species of Centris described by Schrottky were recognized from their labels compared to the original descriptions and the Schrottky's catalogue published by Rasmussen et al. (2009). The acronyms of the institutions cited throughout the text are as follows: Coleção Pe. Jesus S. Moure, Departamento de Zoologia, Universidade Federal do Paraná, Curitiba, Brazil (DZUP); Museo Argentino de Ciencias Naturales Bernardino Rivadavia, Buenos Aires, Argentina (MACN); Museu de Zoologia, Universidade de São Paulo, São Paulo, Brazil (MZSP); and Museum für Naturkunde, Berlin, Germany (ZMB). The specific features of the labels, like coloration or type of writing are presented in squared brackets ([]). All labels are yellowish white (due the effect of time) and rectangular, and the data contained on them is black, handwritten or printed, unless otherwise indicated. The images were originally published by Ramos et al. (2015) and were obtained from a Leica M205C stereoscope attached to a Leica DFC 295 video camera. The photographs were assembled with the Leica LAS (Leica Application Suite V3.6.0) and Helicon Focus (version 6.0.18) - render method based on Method $C$ (Pyramid) and enhanced with Photoshop (ver. 7.0). The copyright of the photographs belongs to the MZSP. The morphological terminology follows Michener (2007).

\section{RESULTS}

\section{Systematics}

\section{Genus Centris Fabricius, 1804}

\section{Centris anisitsi (Schrottky, 1908)}

Hemisia anisitsi Schrottky, 1908: 141.

Type data: This species was described based on a single male collected in Asunción, Paraguay by the Hungarian biologist János Dániel Anisits (1856-1911). Anisits migrated to Paraguay where he worked actively conducting explorations and collecting biological material (Magyarország és Latin-Amerika, 2019). The holotype is currently housed at ZMB and has the following data label: Asuncion, Paraguay J.D. Anisits [printed] XII 04 [handwritten] $\backslash$ [red label] Type [handwritten in white ink] $\backslash$ Hemisia anisitsi Schrottky ơ [handwritten] (ZMB).

Comments: This is a poorly known species only recorded by a couple of specimens collected in Paraguay. Both sexes can be recognized by the square trochanter of fore and middle legs, the yellow pubescence on mesoscutum and mesoscutellum which contrasts with the dark brown to black hairs covering the rest of the body, and by the clypeus and labrum blackish with coarse and very dense punctation.

\section{Centris brethesi Schrottky, 1902}

Centris (Rhodocentris) brethesi Schrottky, 1902c: 117.

Type data: This species was described from a single female specimen collected in the province of San Juan, Argentina. The holotype is currently housed at MACN and it has the following data label: [green label with black rim] Typus [handwritten] \ Centris (Rhodocentris) brethesi Schrottky ?.

Comments: This species has been recorded in the Argentinean Provinces of Buenos Aires, Catamarca, Chubut, Córdoba, Jujuy, La Rioja, Mendoza, Neuquén, Salta, San Juan, San Luis, and Tucumán (Moure et al., 2007). Figures of both sexes can be found in Zanella (2002).

\section{Centris burgdorfi ocellata (Schrottky, 1908)}

Hemisia burgdorfi var. ocellata Schrottky, 1908: 139, 140. Junior synonym of C. burgdorfi Friese, 1901 (RoigAlsina, 2000).

Type data: Schrottky (1908) proposed this variety of C. burgdorfi studying an undetermined number of females and males that belonged to the collection of Anisits collected in Asunción, Paraguay. Moure et al. (2007) were unable to locate the type series and unfortunately it was not found during the development of this article. Its current condition and depository are unknown.

Comments: According to the information on the original description, the type specimens have two spots of yellowish pubescence on the mesonotum. However, the pilosity of $C$. burgdorfi is very variable, being possible to find specimens with the dorsal surface of the mesosoma completely covered by blackish or yellowish pubescence, including intermediary forms. This species has been recorded in Argentina (provinces of Misiones and Corrientes) (Roig-Alsina, 2000), Brazil (Ceará, Distrito Federal, Minas Gerais, Paraná, Pernambuco, Rio Grande do Sul, and São Paulo states) and in Paraguay (Central and Guairá departments) (Moure et al., 2007).

\section{Centris ehrhardti Schrottky, 1902}

Centris ehrhardti Schrottky, 1902b: 579. Junior synonym of C. dorsata (Friese 1904; Schrottky, 1904).

Type data: Schrottky (1902b) described this species from a couple of males collected by Wilhelm Ehrhardt in Rincão, southeastern Brazil. Ehrhardt (1860-1936) was a Guyana-born German animal collector and an excellent taxidermist that operated in Brazil around the early $20^{\text {th }}$ century. He collected thousands of specimens of various animal groups, among them some amphibian, fish, 
mammal and insect species (Gutsche et al., 2007). Both syntypes are housed at MZSP being here designated the lectotype the one in best condition (Figs. 2A, B). The specimen has the following data label: 97250 [printed] 1360 [handwritten] $\sigma^{\prime \prime}$ [handwritten]. The paralectotype has the following data label: 97250 [printed] $\backslash 1360$ [handwritten] $\backslash \sigma^{x}$ [handwritten].

Comments: Schrottky (1902b) mentioned that the type specimens were collected on a Caesalpiniaceae, probably Cassia sp. According to the accession book at MZSP the number 1,360 refers to the following data: "Brazil, São Paulo, Rincão, ii.1901, D. Ehrardt col" (Ramos et al., 2015). Centris dorsata has been recorded in Bolivia (Cochabamba department) and Brazil (Goiás, Mato Grosso do Sul, Minas Gerais, Paraná, Santa Catarina, and São Paulo states) (Moure et al., 2007).

\section{Centris furcata friesei Schrottky, 1902}

Centris (Melanocentris) furcata var. friesei Schrottky, 1902a: 312. Junior synonym of C. obsoleta Lepeletier, 1841 (Friese, 1904).

Type data: This variety was proposed based on an undetermined number of males collected in São Paulo state, southeastern Brazil. Moure et al. (2007) mentioned the existence of a holotype housed at MZSP but no primary types of this species were found in that collection (Ramos et al., 2015). The current condition and depository are unknown.

Comments: According to the original description (Schrottky, 1902a) the type specimen was deposited in Schrottky's own collection. Unfortunately, it is very probable that the type specimen is lost or destroyed, as well as a large number of his primary types (Rasmussen et al., 2009). Centris obsoleta is widely distributed in South America, being recorded in Argentina (Corrientes province), Brazil (Amazonas, Ceará, Mato Grosso, Pará, and São Paulo states), French Guiana, Paraguay and Venezuela (Mérida state) (Moure et al., 2007). Both sexes of this species have a strong variation in the coloration of the pubescence, which led different authors to describe subspecies, varieties or new species based on this character. Photographs of both sexes can be found in Vivallo \& Zanella (2012).

\section{Centris garleppi (Schrottky, 1913)}

Hemisia garleppi Schrottky, 1913: 708.

Type data: This species was described based on a single female collected by Otto Garlepp in Apurímac, southern Peru. Garlepp (1864-1959) was a German naturalist and, as well as his brother Gustav (1862-1907), a professional collector that worked actively in South America. The holotype is currently housed at DZUP but according to Moure (1999) it belongs to the MZSP. The specimen has the following data label: Apurimac Peru [handwritten] [black-rimmed] Hemisia garleppi Schrottky 9 [handwritten] C.S. Schrottky det. 19 [printed] 12 [handwritten] $\backslash$ recebido de J.F. Zikán Pe Moure 1942 [handwritten].

Comments: This is a poorly known species recorded only in Peru. Considering the dark metasoma with terga 4 to 6 reddish brown, this species is probably related to C. caelebs Friese, 1899 which also has the same pattern of coloration.

\section{Centris lynchi Schrottky, 1902}

Centris (Melanocentris) lynchi Schrottky, 1902a: 312. Junior synonym of C. nigriventris Burmeister, 1876 (Roig-Alsina, 2000).

Type data: This species was described based on an undetermined number of specimens of both sexes collected in the province of San Juan, northwestern Argentina. The type series was not found during the development of this research and it is apparently lost (Roig-Alsina, 2000).

Comments: Schrottky (1902a) dedicated this species to the Argentinean zoologist and ornithologist Enrique Lynch Arribálzaga (1856-1935) who funded with his countryman the botanist, zoologist and geologist Eduardo Ladislao Holmberg (1852-1937) in 1878 "El Naturalista Argentino", the first journal of Natural History of Argentina (López et al., 2008). This species occurs exclusively in Argentina with distribution records in the provinces of Buenos Aires, Catamarca, Chaco, La Rioja, Mendoza, San Luis, Santa Fe, Santiago del Estero, Salta, and Tucumán (Roig-Alsina, 2000).

\section{Centris pectoralis clypeata (Schrottky, 1908)}

Hemisia pectoralis var. clypeata Schrottky, 1908: 142. Junior secondary homonym of C. clypeata Lepeletier, 1841. Junior synonym of C. obsoleta (Moure et al., 2007).

Type data: This species was apparently described based on a single male collected by János Anisits in Asunción, Paraguay. The current condition and depository of the holotype are currently unknown.

Comments: Moure (1950) mentioned the variability in the coloration of the pubescence of $C$. pectoralis Burmeister, $1876(=$ C. obsoleta) indicating that the varieties described of that species must be suppressed, which would include $C$. pectoralis var. clypeata and C. pectoralis var. flava (see below). However, the synonymy between this latter variety and C. obsoleta was only formally indicated by Moure et al. (2007).

\section{Centris pectoralis flava (Schrottky, 1908)}

Hemisia pectoralis var. flava Schrottky, 1908: 142. Junior synonym of C. obsoleta (Moure et al., 2007). 

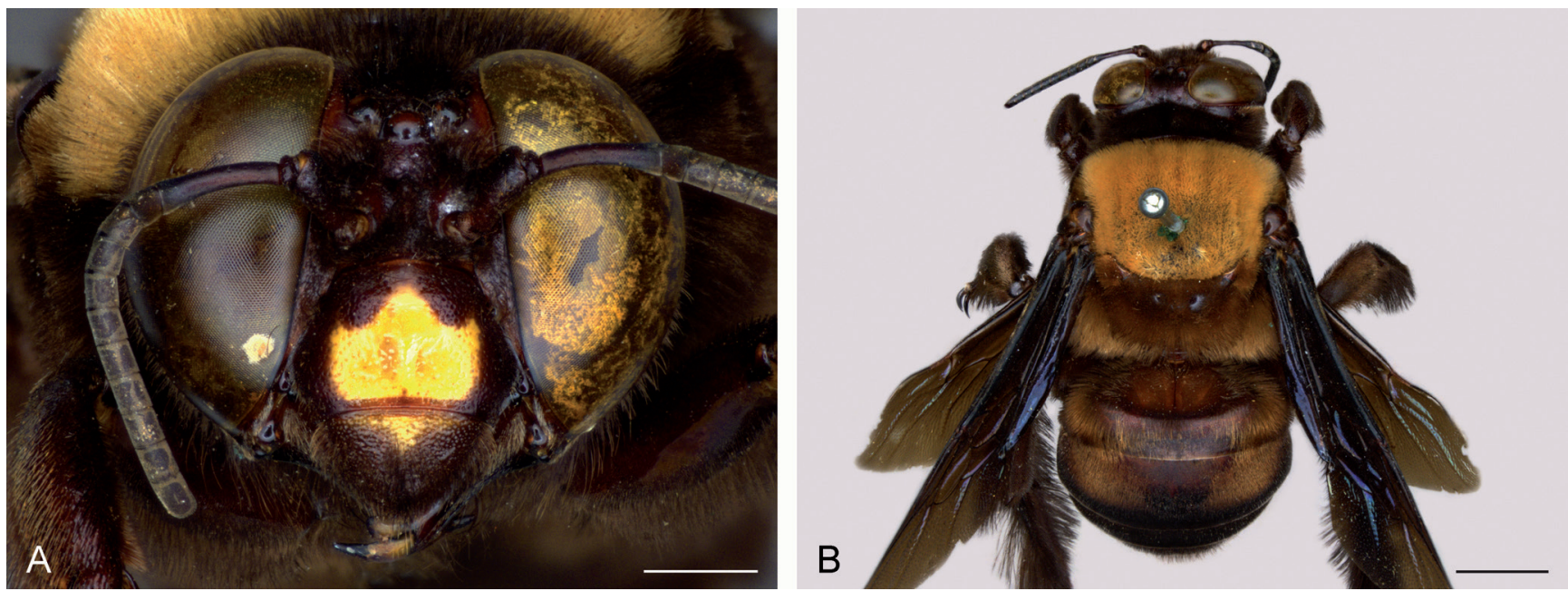

Figure 1. Centris pocograndensis Schrottky, 1902 (holotype male). (A) Head, frontal view (scale bar: $2 \mathrm{~mm}$ ). (B) Habitus, dorsal view (scale bar: $5 \mathrm{~mm}$ ).
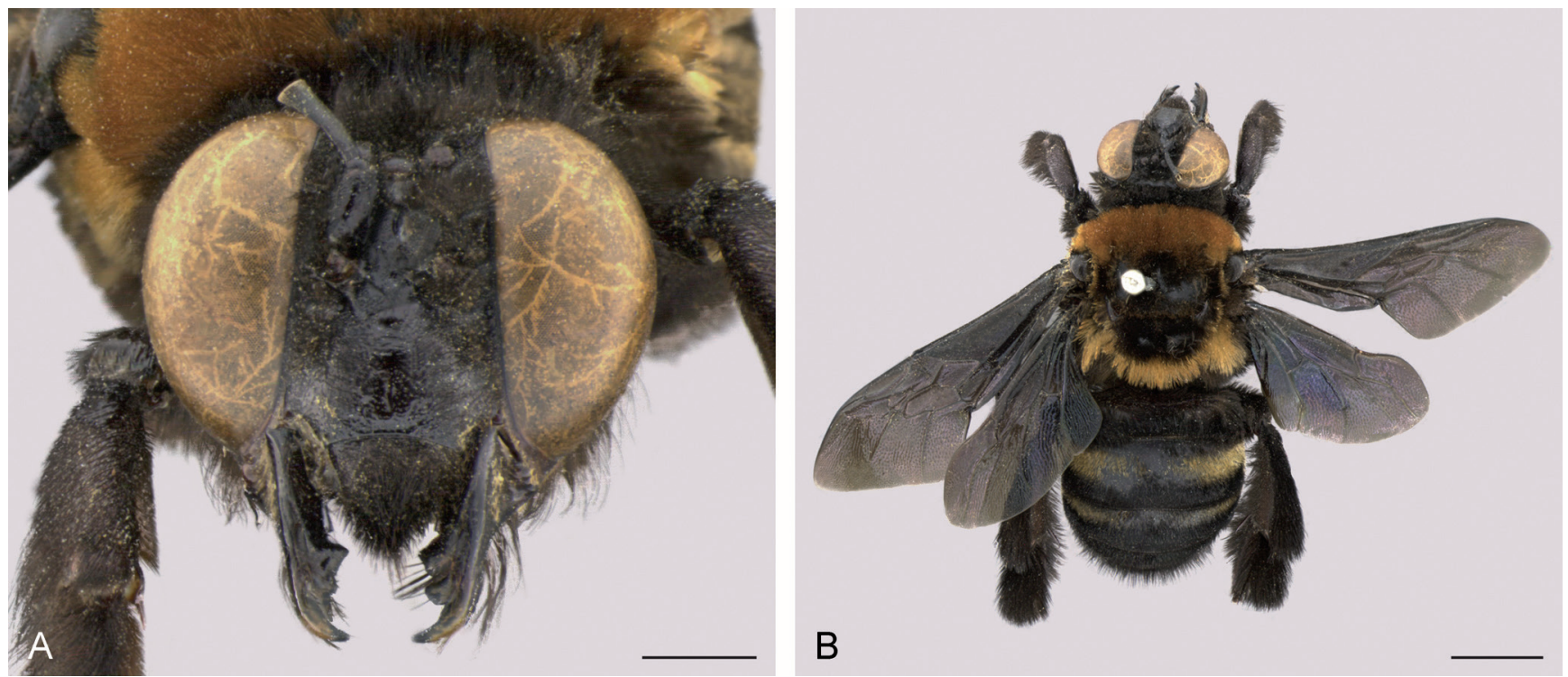

Figure 2. Centris ehrhardti Schrottky, 1902 (lectotype male). (A) Head, frontal view (scale bar: 2 mm). (B) Habitus, dorsal view (scale bar: 5 mm).
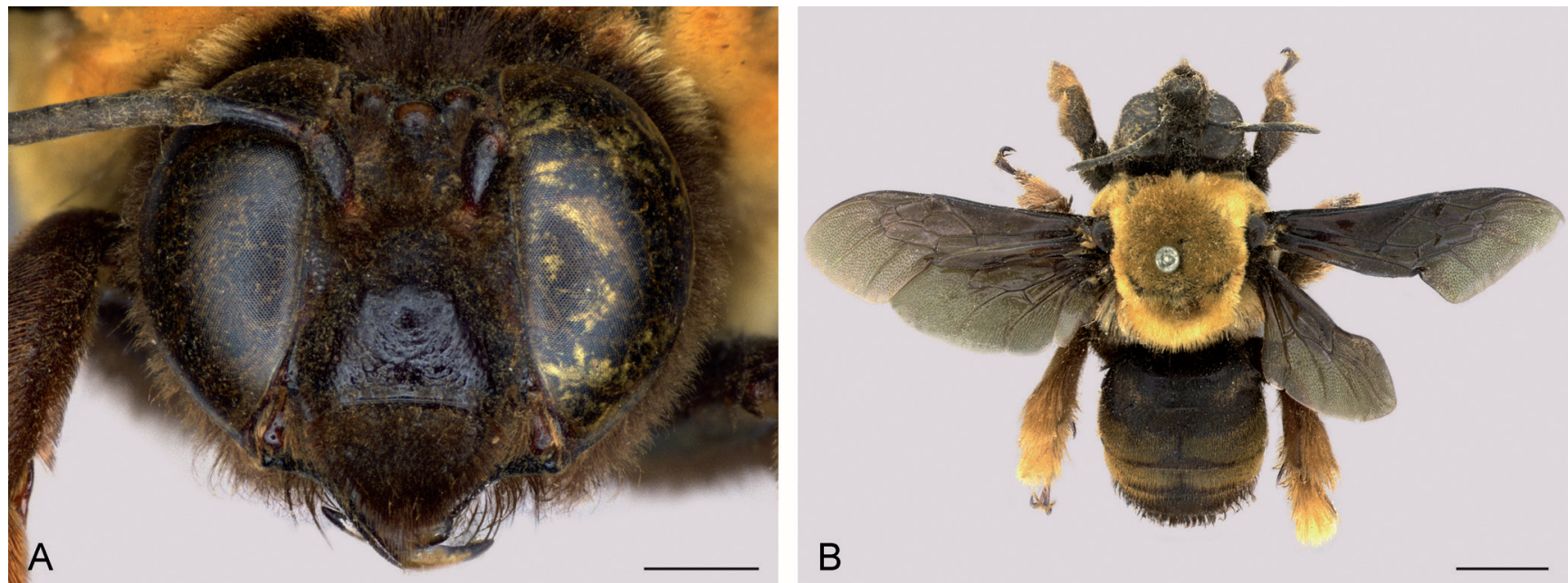

Figure 3. Centris xanthocnemis var. perflava Schrottky, 1902 (holotype male). (A) Head, frontal view (scale bar: $2 \mathrm{~mm}$ ). (B) Habitus, dorsal view (scale bar: $5 \mathrm{~mm}$ ). 
Type data: This variety was proposed based on a single male specimen collected by Janós Anisits, the same collector of the type specimens of C. anisitsi and C. pectoralis var. clypeata in Asunción, Paraguay. Moure et al. (2007) were unable to locate the holotype but it is actually housed at ZMB. The type specimen has the following data label: Asuncion, Paraguay J.D. Anisits [printed] 11.ll.06 im garten [handwritten] \C. pector. f. flava Schrttk. $\sigma^{x}$ [handwritten] Strand det [printed].

Comments: Centris obsoleta is widely distributed in South America with records from Argentina, Brazil, French Guiana, Paraguay, and Venezuela (Moure et al., 2007).

\section{Centris pocograndensis Schrottky, 1902}

Centris poçograndensis Schrottky, 1902b: 578, 579. Junior synonym of $C$. collaris Lepeletier, 1841 (Moure, 2002).

Type data: This species was described based on a single male specimen (Figs. 1A, B) collected in Poço Grande, an old farm near the city of Juquiá (Moure, 2002). The holotype is currently housed at MZSP and it has the following data label: [black rimmed] Centris poçograndensis Shrottky or Poço Grande Brasil [handwritten] \[red label with black rim] Melanocentris poçograndensis (Schr.) $\sigma^{7}$ [handwritten] P. Moure det [printed] 1945 [handwritten] Ducke det. 15. Unico! [handwritten].

Comments: Friese (1904) erroneously mentioned this species as junior synonym of C. dorsata Lepeletier, 1841. Centris collaris has been recorded in Paraguay and in the Brazilian states of Mato Grosso, Minas Gerais and São Paulo (Moure et al., 2007).

\section{Centris unifasciata (Schrottky, 1913)}

Hemisia garleppi var. unifasciata Schrottky, 1913: 708.

Type data: The holotype of C. garleppi var. unifasciata was also collected by Otto Garlepp in the same locality that C. garleppi. The holotype is housed at DZUP, but according to Moure (1999) it also belongs to the MZSP. The specimen has the following data label: Apurimac Peru [handwritten] $\backslash$ [black-rimmed] Hemisia garleppi Schrot. f. unifasciata Schr. $\$$ [handwritten] C.S. Schrottky det. 19 [printed] 12 [handwritten] $\backslash$ M. Zool. USP [handwritten] $\backslash$ [black-rimmed] Centris unifasciata Schr. $\$$ [handwritten] P. Moure det. [printed] 1948 [handwritten] C. (Paracentris) v. unifasciata Schr. [handwritten with blue ink].

Comments: This is a rare species of the subgenus $C$. (Paracentris) only known from the type specimen. It was erroneously cited to Chile by Zanella (2002). Unfortunately, nothing is known about its bionomy or distribution range.

\section{Centris xanthocnemis perflava Schrottky, 1902}

Centris xanthocnemis var. perflava Schrottky, 1902b: 576. Junior synonym of C. xanthocnemis (Perty, 1833) (Moure et al., 2007).

Type data: This variety of Centris xanthocnemis was described based on a single male specimen collected in "Jundiahy" (= Jundiaí), southeastern Brazil (Figs. 3A, B). The holotype is housed at MZSP and it has the following data label: 97262 [printed] 1376 [handwritten] $\backslash$ [red label without text].

Comments: The type specimen was caught by the insect collector Max Beron. It is a male of C. xanthocnemis with yellow pubescence on the mesosoma and hind legs instead of the blackish hairs found in most males. According to the accession book at MZSP the number 1,376 refers to the following data: "Brazil, São Paulo, Jundiaí, M. Beron col" (Ramos et al., 2015).

\section{DISCUSSION}

Schrottky is the seventh major descriptor of Neotropical bees and the second in names proposed currently considered valid (Melo, 2007). Of the 12 species and varieties described by him in the genus Centris, only four of them are at present treated as valid. The main problem with the Centris species described by Schrottky is that they were proposed based on coloration mainly of the pubescence of male specimens. However, this character is very variable in several species of the genus, principally in that sex.

Some of the Schrottky's primary types were not found during the development of this article. According to Rasmussen et al. (2009), several Schrottky's types are currently lost or were destroyed. Unfortunately, it is not clear how many types were effectively destroyed, because part of his collection was widely scattered and sent to several institutions being difficult to track where a specific primary type is currently housed.

Schrottky's descriptions are very generic and short, similar to those made by other melittologists of his time, like Heinrich Friese (1860-1948) and Theodore Dru Alison Cockerell (1866-1948). In general, the species proposed by these three researchers are difficult to identify without examining the primary types of the species they proposed.

\section{ACKNOWLEDGMENTS}

I thank Gabriel Melo (DZUP), Arturo Roig-Alsina (MACN), Carlos Roberto Brandão and Kelli dos Santos Ramos (MZSP) and Michael Ohl (ZMB) for allowing me to visit their institutions to study the specimens under their care. I also thank the anonymous reviewers for their help. Financial support was provided by Conselho Nacional de Desenvolvimento Científico e Tecnológico (CNPq, grant 444320/2014-8), Brazil. This paper is part of the SIGMA project № 21565 MN/ UFRJ and contribution number 41 from the HYMN. 


\section{REFERENCES}

Burmeister, H. 1876. Hymenopterologische Mittheilungen. Stettinger Entomologische Zeitung, 37(1/3): 151-183.

Egler, W. 1963. Adolpho Ducke - Traços biográficos, viagens e trabalhos. Boletim do Museu Paraense Emílio Goeldi, Botânica, 18: 1-129.

Fabricius, J.C. 1804. Systema Piezatorum secundum ordines, genera, species, adjectis synonymis, locis, observationibus, descriptionibus. Brunsvigae, Reichard. 439p.

Friese, H. 1899. Neue arten der Bienengattungen Epicharis Klug und Centris Fabr. Természetrajzi Füzetek, 23: 39-48.

Friese, H. 1901 [1900]. Monographie der Bienengattung Centris (s. lat). Annalen des K.K. Naturhistorischen Hofmuseums (Wien), 15: 237-350.

Friese, H. 1904. Zur Synonymie der Apiden. Zeitschrift für Systematische Hymenopterologie und Dipterologie, 4: 98-100.

Gutsche, A.; Kwet, A.; Kucharzewski, C.; Lingnau, R. \& Günther, R. 2007. Wilhelm Ehrhardt and an evaluation of his amphibians and reptiles held in the Herpetological Collection of the Museum für Naturkunde, Berlin. Zoosystematics and Evolution, 83(1): 80-93. D01

Klug, J.C.F. 1807. Kritische Revision der Beienengattungen in Fabricius neuem Piezatensysteme mit Berücksichtigung der Kirbyschen Bienefamilien und Illiger's Bemerkunde zu Kirbys Monographie. Magazin für Insektenkunde, 6: 200-228.

Lepeletier, A.L.M. 1841. Histoire naturelle des insectes - Hyménoptères, II. Paris, Librairie Encyclopédique de Roret. 680p.

López, H.L.; Miquelarena, A.M. \& Gómez, J.P. 2008. Ictiólogos de la Argentina Eduardo Ladislao Holmberg. ProBiota, FCN y M.UNLP Serie Técnica y Didáctica, 14(1): 1-73.

Magyarország és Latin-Amerika. 2019. Magyarország és Latin-Amerika. Közös Múlt És Jelen. Available at: https://latam.kormany.hu/anisits-janosdaniel. Access in: 12/10/2019.

Melo, G.A.R. 2007. Introductory remarks. In: Moure, J.S.; Urban, D. \& Melo, G.A.R. (Orgs.). Catalogue of Bees (Hymenoptera, Apoidea) in the Neotropical Region. Curitiba, Sociedade Brasileira de Entomologia. 1058p.

Michener, C.D. 2007. The Bees of the World. 2. Ed. Baltimore, Johns Hopkins University Press. 992p.

Moure, J.S. 1950. Alguns agrupamentos novos de abelhas neotropicais (Hymenoptera, Apoidea). Dusenia, 1(6): 385-394.

Moure, J.S. 1999 [2000]. Algumas espécies de Centris (Paracentris) (Hymenoptera, Anthophoridae). Acta Biológica Paranaense, 28(1,2,3,4): 147-158. DOI

Moure, J.S. 2002. Duas espécies novas de Centris Fabricius do Peru e notas sobre duas outras de São Paulo, esquecidas desde a sua descrição
(Hymenoptera, Apoidea, Anthophoridae). Revista Brasileira de Zoologia, 19(2): 159-166. DOI

Moure, J.S.; Melo, G.A.R. \& Vivallo, F. 2007. Centridini Cockerell \& Cockerell. In: Moure, J.S.; Urban, D. \& Melo, G.A.R. (Orgs.). Catalogue of Bees (Hymenoptera, Apoidea) in the Neotropical Region, Curitiba, Sociedade Brasileira de Entomologia. p. 83-142.

Perty, J.A.M. 1833. Delectus animalium articulatorum, quae in itinere per Brasiliam annis MDCCCXVII-MDCCCXX jussu et auspiciis Maxilimiliani Josephi I. Bavariae regis augustissimi peracto collegerunt Dr. J.B. de Spix et Dr. C.F. Ph. de Martius. München, Author's edition. p. 125-224, pls. 25-40.

Ramos, K.S.; Kawada, R. \& Brandão, C.R. 2015. Type specimens of bees (Hymenoptera, Apidae) deposited in the Museu de Zoologia da Universidade de São Paulo, Brazil. Papéis Avulsos de Zoologia, 55(24): 335-361. DOI

Rasmussen, C.; Garcete-Barrett, B.F. \& Gonçalves, R.B. 2009. Curt Schrottky (1874-1937): South American entomology at the beginning of the $20^{\text {th }}$ century (Hymenoptera, Lepidoptera, Diptera). Zootaxa, 2282: 1-50.

Roig-Alsina, A. 2000. Claves para las especies argentinas de Centris (Hymenoptera, Apidae), con descripción de nuevas especies y notas sobre distribución. Revista del Museo Argentino de Ciencias Naturales, 2(2): 171-193.

Schrottky, C. 1902a. Hymenopteres noveaux de I'Amerique Meridionale. Anales del Museo Nacional de Buenos Aires, 7: 309-315.

Schrottky, C. 1902b. Ensaio sobre as abelhas solitarias do Brazil. Revista do Museu Paulista, 5: 330-613.

Schrottky, C. 1902c. Neue Argentinische Hymenopteren. Anales del Museo Nacional de Historia Natural de Buenos Aires, 3(1): 91-117.

Schrottky, C. 1904. Beitrag zur Kenntnis einiger südamerikanischer Hymenopteren. Allgemeine Zeitschrift für Entomologie, 9: 344-349.

Schrottky, C. 1908. Die bisher aus Paraguay bekannten Arten der Bienengattungen Epicharis und Hemisia. (Hym.). Zeitschrift für Systematische Hymenopterologie und Dipterologie, 8: 138-143.

Schrottky, C. 1913. Neue südamerikanische Hymenopteren. Deutsche Entomologische Zeitschrift, 1913: 702-708.

Vivallo, F. \& Zanella, F.C.V. 2012. A new species of Centris (Paracentris) Cameron, 1903 from northeastern Brazil, with a key for the Centris species of the Caatinga region (Hymenoptera: Apidae). Zootaxa, 3298: $1-16$.

Zanella, F.C.V. 2002. Sistemática, filogenia e distribuição geográfica das espécies sul-americanas de Centris (Paracentris) Cameron, 1903 e de Centris (Penthemisia) Moure, 1950, incluindo uma análise filogenética do grupo Centris, sensu Ayala, 1998 (Hymenoptera: Apoidea: Centridini). Revista Brasileira de Entomologia, 46(4): 435-488. 